\title{
Characterization of Oral bacteriome dysbiosis in type 2 diabetic patients
}

Junaid Ahmed Kori ${ }^{1 \#}$, Faizan Saleem ${ }^{1,}$ Saeed Ullah ${ }^{1}$, and M. Kamran Azim ${ }^{2 *}$

${ }^{1}$ H.E.J. Research Institute of Chemistry, International Center for Chemical and Biological

Sciences, University of Karachi, Karachi, Pakistan.

${ }^{2}$ Department of Biosciences, Mohammad Ali Jinnah University, Karachi, Pakistan.

\#Present address: US-Pakistan Center for Advanced Studies in Water, Mehran University of Engineering and Technology, Jamshoro, Pakistan.

*Corresponding author: Prof. Dr. M. Kamran Azim

Address: Mohammad Ali Jinnah University, Department of Biosciences, 22-E, Block 6, PECHS, Karachi, Pakistan.

Phone: +9221-111878787 ext. 137

Fax: +9221-34311327

Email: kamran.azim@jinnah.edu; mkamranazim@yahoo.co.uk 
medRxiv preprint doi: https://doi.org/10.1101/2020.04.09.20052613; this version posted April 11, 2020. The copyright holder for this preprint (which was not certified by peer review) is the author/funder, who has granted medRxiv a license to display the preprint in perpetuity.

All rights reserved. No reuse allowed without permission.

\begin{abstract}
We aimed to characterize the relationship of the oral microbiome with diabetes in Pakistan. Saliva samples were collected from diabetic patients $(n=49)$ and healthy individuals $(n=55)$. $16 \mathrm{~S}$ metagenomics saliva was carried out by NGS technology. We observed that the phylum Firmicutes ( $\mathrm{p}$-value $=0.024$ at $95 \%$ confidence interval) was significantly more abundant among diabetic patients than among the controls. We found that the abundance of phylum Actinobacteria did not significantly vary among both groups in contrast to a similar report from the USA (Long et al., 2017). On genus level, acidogenic bacteria Prevotella (p-value $=0.024$ ) and Leptotrichia $\left(\mathrm{p}\right.$-value $\left.=1.5 \times 10^{-3}\right)$; and aciduric bacteria Veillonella $(\mathrm{p}$-value $=0.013)$ were found to be in higher abundance in diabetic patients. These bacteria are found in dental biofilm and involved in the metabolism of fermentable carbohydrates. Stratified analysis by gender revealed healthy and diabetic females to be more divergent. Abundance of Prevotella ( $\mathrm{p}$-value = $4.4 \times 10-3)$ and Leptotrichia $(\mathrm{p}$-value $=0.015)$ was significantly associated with male patients. A comparison of oral bacteriome between two groups revealed the dominance of acidogenic and aciduric bacteria in diabetics which suggested the involvement of these eubacteria in oral dysbacteriosis in diabetes mellitus.
\end{abstract}

Keywords: 16S rRNA; Diabetes; Dysbiosis; Metagenomics; Oral microbiome. 


\section{Introduction}

Diabetes mellitus is deemed as the most prevalent non-communicable disorder throughout the world with a global prevalence of around $8.3 \%$. It is estimated that $\sim 387$ million people are suffering from this metabolic disorder worldwide (90-95\% cases correspond to type 2 diabetes mellitus) [1-3]. It has been asserted that aside from other complications periodontal health is also compromised in type 2 diabetes partly due to alteration in oral microbiome [4].

The human microbiome has been extensively studied in the past few decades because of its dynamicity throughout the body and modulatory potential [5]. The body sites that commonly harbor bacterial communities include oral cavity, skin, vagina, esophagus, colon, etc [6]. Even the secluded and pristine physiological environments (such as nervous system) have recently reported containing bacterial population [7]. A refined estimate based on investigational observations resulted in a ratio of 1.3 bacterial cells per host cell in humans [8].

The term "oral microbiome" has been coined to sum the microbial communities residing in the oral cavity involved in modulation of an array pathophysiological conditions in consortium with each other [8,9]. Bacterial communities in synergetic relationships with each other help to regulate a variety of physiological conditions including pathogen resistance, dysbiosis and immune response [10]. Oral microbiome possesses the capability to transfuse into the bloodstream through the gingival crevice, thus allowing it mobilize throughout the body [11]. Various studies have correlated the oral microbiome with metabolic diseases including dental caries, periodontitis, and gingivitis [12]. An increase in fermentable carbohydrates in the oral cavity or saliva, which is usually the case in diabetes, establishes a favorable environment for the microbes involved in dental caries [13]. The salivary or oral microbiome has been the target of 
medRxiv preprint doi: https://doi.org/10.1101/2020.04.09.20052613; this version posted April 11, 2020. The copyright holder for this preprint (which was not certified by peer review) is the author/funder, who has granted medRxiv a license to display the preprint in perpetuity.

All rights reserved. No reuse allowed without permission.

interest for its diagnostic and prognostic value [14]. During the last decade, studies have focused on the management and prevention of certain and disorders such as dental caries by modulating oral microbiome $[14,15]$.

It has been reported that $\sim 90 \%$ of the oral microbiome cannot be cultured and identified through culturing dependent methods (referred to as "phylotypes" or "uncultivable"). This technical limitation has been a restraint in the identification of a major proportion of oral microbes [16,17]. The application of next-generation DNA sequencing in metagenomics has allowed bypassing these limitations to obtain a considerable microbial profile in a biological system [18]. Periodontal complications have been correlated with variations in the oral microbiome in response to diabetes; however, more data is needed to confer upon such a claim. This study provides additional information on oral bacterial dynamics in type 2 diabetes.

\section{Materials and Methods}

\subsection{Collection of samples}

Before the collection of blood and saliva samples from type 2 diabetic patients and healthy individuals, verbal screening of study participants was carried out. Healthy (non-diabetic) individuals were screened for blood glucose levels and HbA1c according to the authorized guidelines of the American Diabetes Association (ADA). Individuals having un-controlled HbA1c levels (i.e. HbA1c > 6.0), acute or chronic illnesses, periodontal diseases, tobacco usage, pregnancy, and antibiotic usage were not included in the study. Individuals with T2DM according to ADA criteria were selected for the diabetic group. Exclusion criteria for diabetic individuals included current infectious conditions (i.e. white cell count $>11$ ), breastfeeding or pregnancy, medication usage other than anti-diabetics, cancerous malignancies, immunosuppression or immunodeficiency treatment and usage of any form of steroids. According to the exclusion criteria, a total of 104 individuals (i.e. healthy $=55$ and diabetics $=$ 49) were selected for the study. Unstimulated saliva samples were obtained from diabetics and healthy individuals from University Clinic, University of Karachi, Karachi, Pakistan and Civil 
medRxiv preprint doi: https://doi.org/10.1101/2020.04.09.20052613; this version posted April 11, 2020. The copyright holder for this preprint (which was not certified by peer review) is the author/funder, who has granted medRxiv a license to display the preprint in perpetuity.

All rights reserved. No reuse allowed without permission.

Hospital, Karachi, Pakistan with informed consent. The study was approved by the Independent Ethics Committee (IEC), International Center for Chemical and Biological Sciences, University of Karachi, Karachi, Pakistan.

\subsection{DNA extraction and quantification}

CTAB method was used for metagenomic DNA extraction from saliva samples [20]. Metagenomic DNA quantity was assessed using Qubit 2.0 Fluorimeter (Invitrogen Inc. USA). PCR amplification of the hypervariable V3-V4 region of the $16 \mathrm{~S}$ rRNA gene was carried according to "16S Metagenomics Sequencing Library Preparation guidelines" (Illumina Inc. USA) by using T100 thermal cycler (BioRad, USA).

\subsection{Library Preparation, Quantification, Pooling, and 16S rRNA Sequencing}

Multiplexing was performed by attaching the dual indices to the PCR amplicons. Briefly, PCR reaction contained PCR amplicon (5 $\mu \mathrm{L})$, Nextera XT Index Primer 1 (N7XX) (5 $\mu \mathrm{L})$, Nextera XT Index Primer 2 (S5XX) (5 $\mu \mathrm{L}), 2 x$ KAPA HiFi HotStart ReadyMix (25 $\mu \mathrm{L})$, and volume was adjusted to $50 \mu \mathrm{L}$ by PCR grade water. The thermal cycling conditions were set as preheating at $95{ }^{\circ} \mathrm{C}$ for 3 minutes, 8 cycles of $95{ }^{\circ} \mathrm{C}$ for 30 seconds, $55^{\circ} \mathrm{C}$ for 30 seconds, $72{ }^{\circ} \mathrm{C}$ for 30 seconds followed by a final extension at $72{ }^{\circ} \mathrm{C}$ for 5 minutes, and hold at $4{ }^{\circ} \mathrm{C}$. Index PCR cleanup was carried according to the "16S Metagenomics Sequencing Library Preparation" guidelines. Libraries were pooled in equimolar concentration in a single tube. Finally, pooled libraries were sequenced by the MiSeq platform (Illumina Inc., USA) with MiSeq reagent kit V3 (2×300bp).

\subsection{Bioinformatics and Data analysis}

Quality analysis of paired-end NGS reads was carried by FastQC [21]. For quality filtration, Priseq-lite $^{22}$ was used with a minimum length of 75 bases/read, and a minimum, mean quality score of 25. The paired-end reads were assembled by PANDAseq Assembler [23]. The 
medRxiv preprint doi: https://doi.org/10.1101/2020.04.09.20052613; this version posted April 11, 2020. The copyright holder for this preprint (which was not certified by peer review) is the author/funder, who has granted medRxiv a license to display the preprint in perpetuity. All rights reserved. No reuse allowed without permission.

alignment and annotation of 16S rRNA reads were carried against the 16S Microbial Database of NCBI. Annotated NGS reads were then analyzed by MEGAN Metagenome Analyzer [24].

\subsection{Statistical Analysis}

Statistical analysis and heat map plotting was performed by STAMP statistical tool and ClustVis web server, respectively [25,26]. In brief, Welch's t-test with Storey's FDR correction method was utilized for the differential abundance analysis of bacteriome in both studied groups with a cut-off p-value of 0.05. PCA plot was constructed according to ANOVA (Analysis of variance) with Storey's FDR correction at the cut-off p-value of 0.05 .

\section{Results}

\subsection{Clinical data of study participants:}

We carried out $16 \mathrm{~S}$ rRNA metagenomic analysis of oral bacteriome of type 2 diabetic (T2D) patients in comparison with healthy individuals residing in Karachi, Pakistan. Unstimulated saliva samples [healthy $n=55$ (44 males and 11 females); T2D patients $n=49$ (28 males and 21 females)] were collected with the informed consent of participants. The mean age of healthy individuals and patients was $39.7 \pm 11.8$ and 53.1 \pm 7.9 years respectively. The average BMI was 23.8 \pm 3.2 and $25.4 \pm 4.3$ for healthy and diabetics respectively (Table 1).

\subsection{S rRNA metagenomic sequencing and alpha diversity analysis}

In total, 6,126,515 and 4,254,100 next-generation sequence (NGS) raw reads were obtained for samples from healthy individuals $(n=55)$ and diabetic patients $(n=49)$, respectively. The raw reads were filtered according to quality control parameters, which resulted in 4,175,739 and $2,870,792$ reads for healthy individuals and diabetic patients, respectively. The length of filtered sequences was in the range of 250-300 nucleotides. Bioinformatics analysis revealed hundreds of 
medRxiv preprint doi: https://doi.org/10.1101/2020.04.09.20052613; this version posted April 11, 2020. The copyright holder for this preprint (which was not certified by peer review) is the author/funder, who has granted medRxiv a license to display the preprint in perpetuity.

All rights reserved. No reuse allowed without permission.

bacterial genera cumulatively. The number of bacterial genera identified and alpha diversity indices for both groups is given in table 2 (alpha diversity indices of each sample are given in supplementary table 1). Alpha diversity represents the variation of bacterial genera within a particular sample and can be calculated using Shannon and Simpson diversity measurement [27].

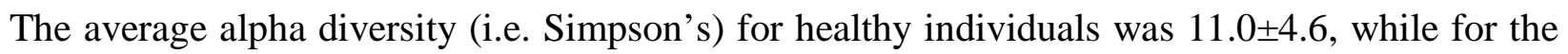
diabetic patients it was observed to be $9.99 \pm 3.7$. Hence, saliva samples from healthy individuals demonstrated slightly higher alpha diversity values in comparison to the samples from diabetic patients.

\subsection{Characterization of salivary bacterial communities}

Substantial bacterial diversity was observed amidst the saliva samples from healthy and diabetic individuals. Among the top 10 bacterial phyla (Figure 1), Proteobacteria (Healthy $=36.3 \%$, Diabetics $=28.5 \%$ ) was predominant in both groups followed by Bacteroidetes (Healthy $=29 \%$, Diabetics $=30.8 \%)$, Firmicutes $($ Healthy $=20.2 \%$, Diabetics $=23.6 \%)$, Fusobacteria $($ Healthy $=$ $6.6 \%$, Diabetics $=7.9 \%$ ) and Actinobacteria (Healthy $=5.0 \%$, Diabetics $=6.2 \%$ ). Figure 2 provides the abundance of bacterial phyla in both groups using Welch's t-test with Storey's FDR correction with $95 \%$ confidence interval. Sequences related to phylum Proteobacteria ( $\mathrm{p}$-value $=$ 0.013) were significantly abundant in healthy individuals, while Firmicutes ( $\mathrm{p}$-value $=0.024$ ) were significantly higher among diabetic patients. Fusobacteria, Actinobacteria and other less dominant phyla demonstrated statistically non-significant variation among both groups.

The NGS reads from all metagenomic samples were annotated according to bacterial genera. Welch's exact test with Storey's FDR correction (p-value of 0.05 and 95\% confidence interval) was carried out to assess the salivary bacterial genera whose population significantly increased in response to diabetes (Figure. 3). The analysis of sequence counts showed that the population of 
medRxiv preprint doi: https://doi.org/10.1101/2020.04.09.20052613; this version posted April 11, 2020. The copyright holder for this preprint (which was not certified by peer review) is the author/funder, who has granted medRxiv a license to display the preprint in perpetuity. All rights reserved. No reuse allowed without permission.

eight bacterial genera significantly elevated among diabetic patients. These bacterial genera included Prevotella and Capnocytophaga (Phylum Bacteroidetes); Veillonella (Phylum Firmicutes); Leptotrichia (Phylum Fusobacteria). Whereas abundance of Pseudomonas (Proteobacteria); Porphyromonas (Bacteroidetes); Stenotrophomonas (Proteobacteria) and Campylobacter (Proteobacteria) decreased in diabetic patients.

Figure 4 illustrates the comparison of the top 40 bacterial genera detected in both studied groups. It was observed that many of the bacterial genera detected in the saliva of healthy individuals were absent in diabetics; while some of the bacterial genera were either exclusive for the saliva of diabetic patients or their population was found to be decreased in healthy individuals. Moreover, the analysis revealed that bacteriome in healthy and diabetic females was more divergent compared to healthy and diabetic males (Figure 4). The similarity threshold PCA plot of healthy and diabetic males resulted in the clustering of the majority of samples in a single area (Figure 5). Figures 6 and 7 demonstrate the gender-based differential abundance profile of healthy and diabetic individuals. The acidogenic bacteriome (i.e. Prevotella, Veillonella, and Leptotrichia) was higher in male and female diabetics but was less in male and female controls. In male diabetics, sequences related to Prevotella $(\mathrm{p}$-value $=0.0044)$ and Leptotrichia $(\mathrm{p}$-value $=$ 0.015) were significantly more abundant. While, in female diabetics, genus Leptotrichia was more abundant (with p-value $=0.056$ ).

\section{Discussion:}

Oral microbiota has been deemed to play a role in the pathogenesis of systemic chronic diseases such as diabetes. It has been estimated that over 700 bacterial species reside in the oral cavity that is involved in the regulation of various immunomodulatory and metabolic processes [28]. Several bacterial species have been reported to be involved in dental caries specifically in 
medRxiv preprint doi: https://doi.org/10.1101/2020.04.09.20052613; this version posted April 11, 2020. The copyright holder for this preprint (which was not certified by peer review) is the author/funder, who has granted medRxiv a license to display the preprint in perpetuity.

All rights reserved. No reuse allowed without permission.

response to the progression of diabetes [29]. The present study provides metagenomics based identification of variation in oral bacteriome in patients with diabetes.

In this study, oral microbiota of healthy $(n=55)$ and diabetic $(n=49)$ individuals was analyzed by next-generation sequencing-based metagenomics. The number of bacterial genera identified varied for each studied individual with a higher diversity of oral bacterial genera in healthy individuals. Shannon and Simpson's diversity indices revealed slightly higher alpha diversity in samples from healthy individuals in comparison to diabetic patients (Supplementary Table 1). Lesser alpha diversity indices in diabetic patients have been attributed to the stressful environmental conditions in the oral cavity due to hyper-mineralization and increased acidouric and/or acidogenic microflora [30].

Evaluation of oral microflora characterized Proteobacteria to be the most abundant bacterial phylum in both groups with a significantly higher population in healthy individuals in comparison to diabetics (Figures 1 and 2). This observation is suggestive of the susceptibility of Proteobacteria in systemic inflammatory metabolic disorders as it has also been described in patients suffering from hepatitis [31].

Moreover, the abundance of Bacteroidetes and Firmicutes was observed to be elevated in the salivary samples of diabetic patients in comparison to healthy individuals. Higher levels of Bacteroidetes have also been characterized in the patients with periodontal diseases [32], while the increase in abundance of Firmicutes has been correlated with higher amount of salivary glucose, which is usually the case for diabetic patients and has been attributed as the favorable environment for the growth of Firmicutes [33]. An increase in inflammatory responses is one of the characteristics of diabetes and the abundance of oral Firmicutes has been correlated with an increase in inflammation [34]. In a study from the USA reported phylum Actinobacteria was 
medRxiv preprint doi: https://doi.org/10.1101/2020.04.09.20052613; this version posted April 11, 2020. The copyright holder for this preprint (which was not certified by peer review) is the author/funder, who has granted medRxiv a license to display the preprint in perpetuity. All rights reserved. No reuse allowed without permission.

present significantly less abundant among the patients with diabetes than among the controls [28]. In contrast, we could not find a statistically significant difference in Actinobacteria among both groups. This population-based difference might be due to variation in lifestyle including dietary habits.

Several bacterial genera were found to be either exclusively or in higher abundance in the saliva of diabetics (Figure 4). Sequences related to genus Neisseria were unique to male diabetic patients. It has been proposed in a previous study that this genus is involved in the development of the anaerobic environment in the oral cavity which promotes the growth of nitrate-reducing bacteria which in turn provides a favorable environment for the opportunistic pathogens [35]. Genus Gemella that was exclusively present in saliva samples of female diabetics has been reported to be increased in abundance during the onset and progression of inflammatory bowel disease [15]. Genera Capnocytophaga and Actinomyces were observed to be abundant in both male and female groups which are in agreement with a previous study [36]. Species of genus Capnocytophaga are normal inhabitants of the oropharyngeal cavity. Species of this genus have been reported as the causal agents of dental caries and other periodontal diseases in immunocompromised patients [37]. Sequences related to acidogenic bacterial genera including Prevotella, Veillonella, and Leptotrichia were significantly increased in diabetics compared to healthy individuals (Figure 3). The species of bacterial genera are involved in metabolic utilization of carbohydrates which results in acid production (e.g. lactic acid etc.), thus creating an acidic salivary environment [33]. Species of Prevotella have been characterized as the members of oral, vaginal and gut bacterial communities. The abundance of Prevotella species occurs in response to an increase in carbohydrate intake [38]. An increase in the abundance of Prevotella species has been correlated with periodontal diseases [39]. Veillonella species are 
medRxiv preprint doi: https://doi.org/10.1101/2020.04.09.20052613; this version posted April 11, 2020. The copyright holder for this preprint (which was not certified by peer review) is the author/funder, who has granted medRxiv a license to display the preprint in perpetuity.

All rights reserved. No reuse allowed without permission.

normal inhabitants of the oral cavity with lactic acid fermentation capability and are correlated with intraradicular infections of apical root canal and dental tubules [40]. Leptotrichia species are also members of normal oral flora, which possess lactic acid fermentation ability and characterized as opportunistic pathogens leading to dental caries such as tooth decay [41]. Acidification of the salivary environment in diabetic patients may lead to deterioration of oral and dental health.

The present study provides an overview of variations in oral microflora of diabetic patients in comparison to healthy individuals and might aid in the proficient assessment of complications underlying onset and progression of diabetes.

\section{Conflict of interest}

The authors declare no conflict of interest.

\section{References}

1. Nazir SUR, Hassali MA, Saleem F, Bashir S, Aljadhey H (2016). Disease related knowledge, medication adherence and glycaemic control among patients with type 2 diabetes mellitus in Pakistan. Prim Care Diabetes, 10(2): 136-141. https://doi.org/10.1016/j.pcd.2015.09.004

2. Atlas ID, (2015). International diabetes federation, Brussels, 2015. Available from: http://www.idf.org/diabetesatlas/5e/the-global-burden.

3. American Diabetes Association, 2016. 2. Classification and diagnosis of diabetes. Diabetes care, 39(Supplement 1): S13-S22. https://doi.org/10.2337/dc15-S005

4. Shillitoe E, Weinstock R, Kim T, Simon H, Planer J, Noonan S. and Cooney R, (2012). The oral microflora in obesity and type-2 diabetes. J Oral Microbiol, 4(1):19013. https://doi.org/10.3402/jom.v4i0.19013 
medRxiv preprint doi: https://doi.org/10.1101/2020.04.09.20052613; this version posted April 11, 2020. The copyright holder for this preprint (which was not certified by peer review) is the author/funder, who has granted medRxiv a license to display the preprint in perpetuity. All rights reserved. No reuse allowed without permission.

5. Marcobal A, Kashyap PC, Nelson TA, Aronov PA, Donia MS, Spormann A, Fischbach MA, and Sonnenburg JL, (2013). "A metabolomic view of how the human gut microbiota impacts the host metabolome using humanized and gnotobiotic mice." ISME $J$ 7, no. 10:1933. https://doi.org/10.1038/ismej.2013.89

6. Gilbert Jack A, Martin J Blaser, J. Gregory Caporaso, Janet K. Jansson, Susan V. Lynch, and Rob Knight (2018). "Current understanding of the human microbiome." Nat Med 24, no. 4:392. https://doi.org/10.1038/nm.4517

7. Roberts RC, Farmer CB, Walker CK, (2018). Psychiatry and Behavioral Neurobio., Univ. of Alabama, Birmingham, Birmingham, AL. The human brain microbiome; there are bacteria in our brains!. Program No. 594.08. 2018 Neuroscience Meeting Planner. San Diego, CA: Society for Neuroscience, 2018. Online.

8. Dewhirst FE, Chen T, Izard J, Paster BJ., Tanner AC, Yu WH, Lakshmanan A, and Wade WG, (2010). The human oral microbiome. J Bacteriol, 192(19): 5002-5017. https://doi.org/10.1128/JB.00542-10

9. Zhao H, Chu M, Huang Z, Yang X, Ran S, Hu B, Zhang C, Liang J (2017). Variations in oral microbiota associated with oral cancer. Sci Rep-Uk, 7(1): 11773. https://doi.org/10.1038/s41598-017-11779-9

10. He J, Li Y, Cao Y, Xue J, Zhou X (2015). The oral microbiome diversity and its relation to human diseases. Folia Microbiol, 60(1): 69-80. https://doi.org/10.1007/s12223-014$\underline{0342-2}$

11. Wade, William G. "The oral microbiome in health and disease." Pharmacol Res 69, no. 1 (2013): 137-143. https://doi.org/10.1016/j.phrs.2012.11.006 
medRxiv preprint doi: https://doi.org/10.1101/2020.04.09.20052613; this version posted April 11, 2020. The copyright holder for this preprint (which was not certified by peer review) is the author/funder, who has granted medRxiv a license to display the preprint in perpetuity. All rights reserved. No reuse allowed without permission.

12. Olsen, Ingar (2016). "The oral microbiome in health and disease." In Oral infections and general health, pp. 97-114. https://doi.org/10.1007/978-3-319-25091-5 10

13. Wade, William G. "Characterisation of the human oral microbiome." Journal of Oral Biosciences 55, no. 3 (2013): 143-148. https://doi.org/10.1016/j.job.2013.06.001

14. Lazarevic V, Whiteson K, Gaïa N, Gizard Y, Hernandez D, Farinelli L, Østerås M, François P, Schrenzel J (2012). Analysis of the salivary microbiome using cultureindependent techniques. J. Clin. Bioinf, 2(1): 4. https://doi.org/10.1186/2043-9113-2-4

15. Acharya A, Chan Y, Kheur S, Jin LJ, Watt RM, Mattheos N (2017). Salivary microbiome in non-oral disease: A summary of evidence and commentary. Arch Oral Biol, 83: 169173. https://doi.org/10.1016/j.archoralbio.2017.07.019

16. Belstrøm D, Paster BJ, Fiehn NE, Bardow A, Holmstrup P., (2016). Salivary bacterial fingerprints of established oral disease revealed by the Human Oral Microbe Identification using Next Generation Sequencing (HOMI NGS) technique. J Oral Microbiol, 8(1): 30170. https://doi.org/10.3402/jom.v8.30170

17. Krishnan K, Chen T, Paster BJ, (2017). A practical guide to the oral microbiome and its relation to health and disease. Oral Dis, 23(3): 276-286. https://doi.org/10.1111/odi.12509

18. Belstrøm D, Holmstrup P, Fiehn NE, Rosing K, Bardow A, Paster BJ, Lynge Pedersen AM (2016). Bacterial composition in whole saliva from patients with severe hyposalivation-a case-control study. Oral Dis, 22(4): 330-337. https://doi.org/10.1111/odi.12452

19. Aagaard K, Petrosino J, Keitel W, Watson M, Katancik J, Garcia N, Patel S, Cutting M, Madden T, Hamilton H, Harris E (2013). The Human Microbiome Project strategy for 
medRxiv preprint doi: https://doi.org/10.1101/2020.04.09.20052613; this version posted April 11, 2020. The copyright holder for this preprint (which was not certified by peer review) is the author/funder, who has granted medRxiv a license to display the preprint in perpetuity. All rights reserved. No reuse allowed without permission.

comprehensive sampling of the human microbiome and why it matters. Faseb J, 27(3): 1012-1022. https://doi.org/10.1096/fj.12-220806

20. Nishiguchi MK, Doukakis P, Egan M, Kizirian D, Phillips A, Prendini L, Giribet, G (2002). DNA isolation procedures. Tech Mol Evol Syst, 249-287. https://doi.org/10.1007/978-3-0348-8125-8_12

21. Andrews S, (2010). FastQC: a quality control tool for high throughput sequence data. Available online at: http://www.bioinformatics.babraham.ac.uk/projects/fastqc

22. Schmieder R, Edwards R (2011). Quality control and preprocessing of metagenomic datasets. Bioinformatics, 27(6):863-864. https://doi.org/10.1093/bioinformatics/btr026

23. Masella AP, Bartram AK, Truszkowski JM, Brown DG, Neufeld JD (2012). PANDAseq: paired-end assembler for illumina sequences. BMC Bioinf, 13(1): 31. https://doi.org/10.1186/1471-2105-13-31

24. Huson DH, Weber N (2013). Microbial community analysis using MEGAN. Method Enzymol. 531: 465-485 https://doi.org/10.1016/B978-0-12-407863-5.00021-6

25. Parks DH, Tyson GW, Hugenholtz P, Beiko RG (2014). STAMP: statistical analysis of taxonomic and functional profiles. Bioinformatics, 30(21): 3123-3124. https://doi.org/10.1093/bioinformatics/btu494

26. Metsalu T, Vilo J (2015). ClustVis: a web tool for visualizing clustering of multivariate data using Principal Component Analysis and heatmap. Nucleic Acids Res, 43(W1): 566-570. https://doi.org/10.1093/nar/gkv468

27. Keylock, C. J (2005). "Simpson diversity and the Shannon-Wiener index as special cases of a generalized entropy." Oikos 109, no. 1: 203-207. https://doi.org/10.1111/j.0030$\underline{1299.2005 .13735 . x}$ 
medRxiv preprint doi: https://doi.org/10.1101/2020.04.09.20052613; this version posted April 11, 2020. The copyright holder for this preprint (which was not certified by peer review) is the author/funder, who has granted medRxiv a license to display the preprint in perpetuity. All rights reserved. No reuse allowed without permission.

28. Long J, Cai Q, Steinwandel M, Hargreaves MK, Bordenstein SR, Blot WJ, Zheng W, Shu XO, (2017). Association of oral microbiome with type 2 diabetes risk. J Periodontal Res, 52(3): 636-643. https://doi.org/10.1111/jre.12432

29. Kampoo K, Teanpaisan R, Ledder G, McBain AJ, (2014). Oral bacterial communities in individuals with type 2 diabetes who live in southern Thailand. Appl Environ Microb, 80(2): 662-671. http://doi.org/10.1128/AEM.02821-13

30. Jiang W, Ling Z, Lin X, Chen Y, Zhang J, Yu J, Xiang C, Chen H (2014). Pyrosequencing analysis of oral microbiota shifting in various caries states in childhood. Microb Ecol, 67(4): 962-969. https://doi.org/10.1007/s00248-014-0372-y

31. Ling Z, Liu X, Cheng Y, Jiang X, Jiang H, Wang Y, Li L (2015). Decreased diversity of the oral microbiota of patients with hepatitis B virus-induced chronic liver disease: a pilot project. Sci Rep-Uk 5: 17098. https://doi.org/10.1038/srep17098

32. Griffen AL, Beall CJ, Campbell JH, Firestone ND, Kumar PS, Yang ZK, Podar M, Leys EJ (2012). Distinct and complex bacterial profiles in human periodontitis and health revealed by 16S pyrosequencing. ISME J 6: 1176-1185. https://doi.org/10.1038/ismej.2011.191

33. Goodson JM, Hartman ML, Shi P, Hasturk H, Yaskell T, Vargas J, Song X, Cugini M, Barake R, Alsmadi O, Al-Mutawa S (2017). The salivary microbiome is altered in the presence of a high salivary glucose concentration. PLoS One, 12(3): e0170437. https://doi.org/10.1371/journal.pone.0170437

34. Demmer RT, Breskin A, Rosenbaum M, Zuk A, LeDuc C, Leibel R, Paster B, Desvarieux M, Jacobs Jr DR, Papapanou PN. (2017). The subgingival microbiome, systemic inflammation and insulin resistance: the oral infections, glucose intolerance and insulin resistance study. $J$ Clin Periodontol, 44(3): 255-265. https://doi.org/10.1111/jcpe.12664 
medRxiv preprint doi: https://doi.org/10.1101/2020.04.09.20052613; this version posted April 11, 2020. The copyright holder for this preprint (which was not certified by peer review) is the author/funder, who has granted medRxiv a license to display the preprint in perpetuity. All rights reserved. No reuse allowed without permission.

35. R, Srikanth P, Mani M, Barani R, Seshadri KG, Janarthanan R, (2017). Next generation sequencing of oral microbiota in Type 2 diabetes mellitus prior to and after neem stick usage and correlation with serum monocyte chemoattractant-1. Diabetes Res Clin Pr, 130,; 204-210. https://doi.org/10.1016/j.diabres.2017.06.009

36. Johansson I, Witkowska E, Kaveh B, Lif Holgerson P, Tanner ACR, (2016). The microbiome in populations with a low and high prevalence of caries. J Dent Res, 95(1): 80-86. https://doi.org/10.1177/0022034515609554

37. Chen C, Hemme C, Beleno J, Shi ZJ, Ning D, Qin Y, Tu Q, Jorgensen M, He Z, Wu L. and Zhou J, (2018). Oral microbiota of periodontal health and disease and their changes after nonsurgical periodontal therapy. ISME J, 12(5), p.1210. https://doi.org/10.1038/s41396-0170037-1

38. Wu GD, Chen J, Hoffmann C, Bittinger K, Chen YY, Keilbaugh SA, Bewtra M, Knights D, Walters WA, Knight R. and Sinha R, (2011). Linking long-term dietary patterns with gut microbial enterotypes. Science, 334(6052), pp.105-108. https://doi.org/10.1126/science.1208344

39. Tanaka S, Yoshida M, Murakami Y, Ogiwara T, Shoji M, Kobayashi S, Watanabe S, Machino M. and Fujisawa S, (2008). The relationship of Prevotella intermedia, Prevotella nigrescens and Prevotella melaninogenica in the supragingival plaque of children, caries and oral malodor. J Clin Pediatr Dent, 32(3), pp.195-200.

40. Mashima, I., Theodorea, C.F., Thaweboon, B., Thaweboon, S. and Nakazawa, F., 2016. Identification of Veillonella species in the tongue biofilm by using a novel one-step polymerase chain reaction method. PLoS One, 11(6), p.e0157516. https://doi.org/10.1371/journal.pone.0157516 
medRxiv preprint doi: https://doi.org/10.1101/2020.04.09.20052613; this version posted April 11, 2020. The copyright holder for this preprint (which was not certified by peer review) is the author/funder, who has granted medRxiv a license to display the preprint in perpetuity. All rights reserved. No reuse allowed without permission.

41. Eribe, E.R. and Olsen, I., 2017. Leptotrichia species in human infections II. J Oral Microbiol, 9(1), p.1368848. https://doi.org/10.1080/20002297.2017.1368848 


\begin{tabular}{|c|c|c|c|}
\hline & Healthy & Diabetics \\
\hline \multicolumn{2}{|c|}{ Number of participants } & 55 & 49 \\
\hline \multicolumn{2}{|l|}{ Male/Female } & $44 / 11$ & $28 / 21$ \\
\hline \multicolumn{2}{|c|}{ Age (years \pm SD) } & $39.7 \pm 11.8$ & $53.1 \pm 7.9$ \\
\hline \multicolumn{2}{|l|}{ BMI (kg/m2 } & $23.8 \pm 3.2$ & $25.4 \pm 4.3$ \\
\hline \multicolumn{2}{|c|}{ HbA1c percentage } & $5.2 \pm 0.4$ & $8.3 \pm 1.7$ \\
\hline \multirow[t]{3}{*}{ Smokers } & Regular smoker & 0 & 1 \\
\hline & Non-regular times & 2 & 3 \\
\hline & Non smokers & 46 & 36 \\
\hline $\begin{array}{l}\text { Other } \\
\text { addictions } \\
\text { (may or may } \\
\text { not include } \\
\text { tobacco) }\end{array}$ & (betal nuts/naswar/gutka/chalya) & 1 & 5 \\
\hline \multirow{3}{*}{$\begin{array}{l}\text { Oral } \\
\text { hygiene; } \\
\text { Brushing } \\
\text { habit }\end{array}$} & Daily & 48 & 29 \\
\hline & Alternatively & 0 & 1 \\
\hline & Randomly & 3 & 8 \\
\hline \multirow{3}{*}{$\begin{array}{l}\text { Oral } \\
\text { hygiene; } \\
\text { Brush type }\end{array}$} & Tooth Paste & 32 & 21 \\
\hline & Brushing stick (Miswak) & 7 & 9 \\
\hline & Both & 4 & 6 \\
\hline
\end{tabular}

Table. 1 General characteristics and medical profile of healthy $(n=55)$ and diabetic $(n=49)$ studied individuals.

\begin{tabular}{|l|c|c|c|c|}
\hline & & $\begin{array}{l}\text { Number of } \\
\text { bacterial } \\
\text { genera } \\
\text { identified }\end{array}$ & $\begin{array}{l}\text { Simpson's } \\
\text { reciprocal index }\end{array}$ & $\begin{array}{l}\text { Shannon-Weaver } \\
\text { index }\end{array}$ \\
\hline \multirow{2}{*}{ Healthy } & Total & 3,993 & 604.76 & 229.09 \\
\hline \multirow{2}{*}{ Diabetics } & Average & 72.6 & $11.0 \mathrm{SD} \pm 4.6$ & $4.17 \mathrm{SD} \pm 0.6$ \\
\cline { 2 - 5 } & Total & 3,754 & 489.48 & 199.09 \\
\cline { 2 - 5 } & Average & 77 & $9.99 \mathrm{SD} \pm 3.7$ & $4.06 \mathrm{SD} \pm 0.5$ \\
\hline
\end{tabular}

Table 2: Number of genera, alpha diversity in Simpson's and Shannon-Weaver indices of healthy $(n=55)$ and type 2 diabetics $(n=49)$. 


\section{Figure Legends:}

Figure 1. Percent bar plot demonstrating abundance of top 10 bacterial phyla in saliva of healthy $(\mathrm{n}=55)$ and diabetic $(\mathrm{n}=49)$ individuals.

Figure 2. Extended error bar plot representing Welch's t-test based differential abundance profile of bacterial phyla in healthy $(n=55)$ and diabetic $(n=49)$ individuals at $95 \%$ confidence interval with Storey's FDR correction.

Figure 3. Extended error bar plot representing Welch's t-test (p-value $\leq 0.05$ ) based differential abundance profile of bacterial genera in healthy $(n=55)$ and diabetic $(n=49)$ individuals at $95 \%$ confidence interval with Storey's FDR correction.

Figure 4. Gender based Heat map plot illustration of top 40 bacterial genera in healthy $(\mathrm{n}=55)$ and diabetic $(\mathrm{n}=49)$ individuals.

Figure 5. Principle component analysis demonstrating ANOVA (p-value $\leq 0.05$ ) based similarity profile of samples from healthy males $(n=44)$ and diabetic males $(n=28)$.

Figure 6. Extended error bar plot representing Welch's t-test based differential abundance profile of bacterial genera in healthy males $(n=44)$ and diabetic males $(n=28)$ individuals at $95 \%$ confidence interval with Storey's FDR correction.

Figure 7. Extended error bar plot representing Welch's t-test based differential abundance profile of bacterial genera in healthy females $(n=9)$ and diabetic females $(n=19)$ individuals at $95 \%$ confidence interval with Storey's FDR correction. 


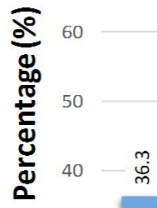

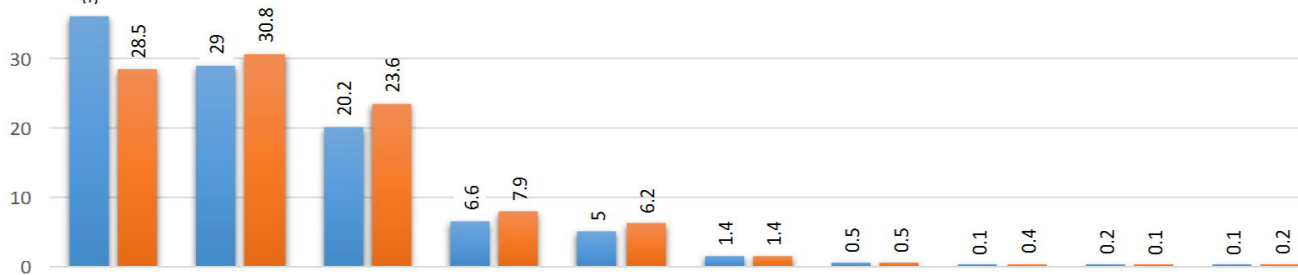

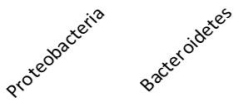

सn
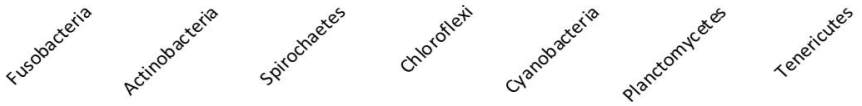

Healthy Diabetics 


\section{$\square$ Diabetic

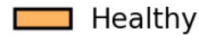 \\ $95 \%$ confidence intervals}

Proteobacteria

Firmicutes

Bacteroidetes

Fusobacteria

Actinobacteria

Spirochaetes 最

Tenericutes |

Synergistetes |

Cyanobacteria |

Chloroflexi $\mathbf{f}$

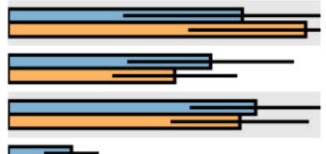

एक

ह-

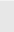

(2)

Planctomycetes $\mathbf{F}$

0.0

$36.2-15$

Mean proportion (\%)

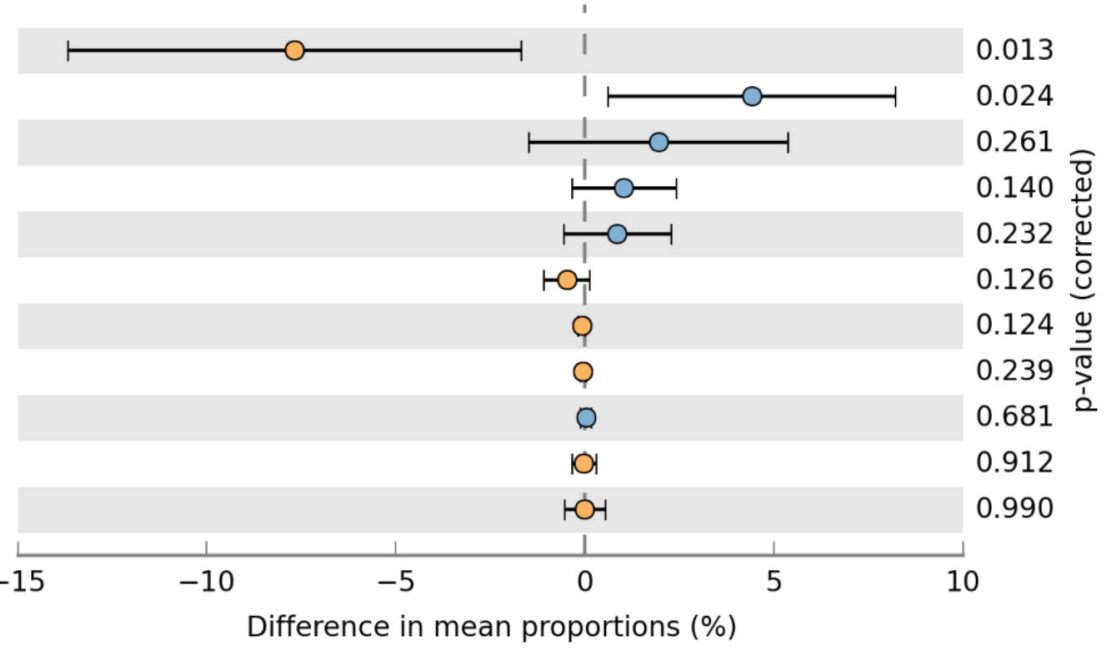


$95 \%$ confidence intervals

Prevotella

Veillonella

Pseudomonas

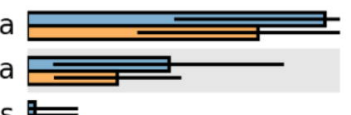

Stenotrophomonas

Porphyromonas

Leptotrichia
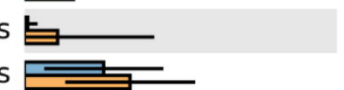

$$
0.0
$$$$
\begin{array}{ll}
18.2 & -6
\end{array}
$$

Mean proportion (\%)

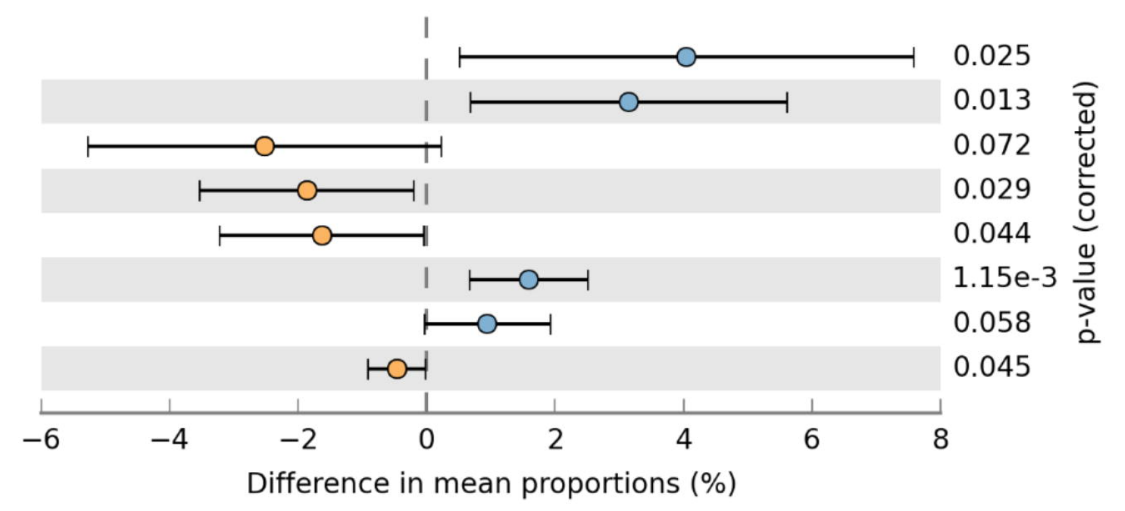





\section{Healthy Males}

$n=44$

(⿸丆口
Diabetic Males

$n=28$

O

口 0 م

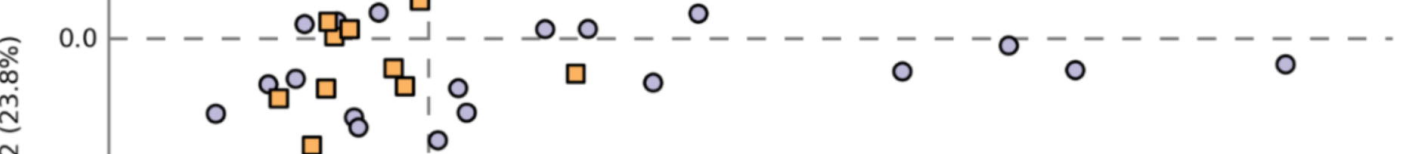

$-0.1-\square 00$

$\square$

$\mathrm{OO}_{\mathrm{i}}$

$\square$

$\square$

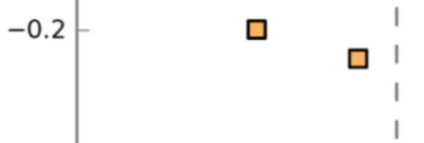

$\begin{array}{rrr}-0.3-\square & 1 \\ \square \quad & 1\end{array}$

$-0.1$

0.1

0.3

0.4

PC1 (33.3\%) 


\section{$\square$ Healthy Males $\square$ Diabetic Males}

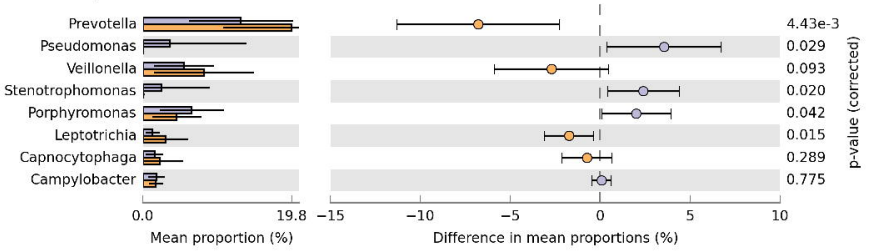


